\title{
The Relationship between Mothers' Knowledge, Attitude and Behavior to Meet Toddlers' Nutritional Needs Status at the Work Area of UPT Puskesmas Ajangale 2021
}

\author{
Hasnidar ${ }^{1}$, Mustar ${ }^{2}$ \\ ${ }^{1,2}$ Institut Sains Dan kesehatan Bone \\ Corresponding Author: Hasnidar
}

\begin{abstract}
Nutrition is one of the determinants of the human resources' quality. Food served daily have to fit nutrients as needed, so it may support optimal growth and can prevent deficiency diseases, prevent poisoning, and also help prevent diseases that can interfere to children's growth. The attitude of mother in providing nutritional supplementary for children is something that can determine how to behave in providing food supplementary and family nutrition, especially for toddlers. Toddler period is characterized by a very rapid growth and development process and is accompanied by changes that require more nutrients in high quality. Food consumption has an important role in the physical growth and intelligence of children so that food consumption has a major effect on the nutritional status of children to achieve the physical growth and intelligence of children. The purpose of this study was to determine the relationship among knowledge, attitudes and behavior of mothers to the nutritional status of children under five/toddlers at (Unit of Technical Implementation) UPT Public Health Centre (Puskesmas) Ajangale. This type of research is descriptive correlational research. The number of samples was 40 mothers who had toddlers. The research analysis used bivariate test. Based on the results of the study showed that there was a relationship between mothers' knowledge in nutrition and the nutritional status of toddlers with the chi square test results obtained p-value $=0.001 \mathrm{p}$ $<0.05$. And there is a relationship between mother's attitude and nutritional status of
\end{abstract}

toddlers with the Chi square test results obtained $\mathrm{p}$-value $=0.001 \mathrm{p}<0.05$. And there is a relationship between mothers' behavior and the nutritional status of children under five/toddlers with the chi square test results obtained p-value $=0.001 \mathrm{p}<0.05$. It is recommended to health workers, especially midwives, to provide counseling to improve understanding related to the importance to meet nutrition in toddlers needs, starting from exclusive breastfeeding until the age of two and serving weaning food (MP-ASI) appropriately and adequately as an effort to prevent and handle stunting cases in Bone Regency.

Keywords: Toddler Nutrition Status, Knowledge, Attitude and Behavior

\section{INTRODUCTION}

Nutrition is one of the determinants of human resources' quality. Food served daily has to meet nutrients as needed to support optimal growth and prevent deficiency diseases, prevent poisoning, and also help prevent diseases that can interfere with children's growth (Soekirman 2011). To produce good human resources (HR), nutritional needs must also be met because good nutrition must be started as early as possible for the growth of children, the growth and development, health care and recovery and immunity. However, currently the nutritional needs are still problematic and a central issue. According to (UNICEF 2018), nutritional problems in children at 
Hasnidar et.al. The relationship between mothers' knowledge, attitude and behavior to meet toddlers' nutritional needs status at the work area of UPT Puskesmas Ajangale 2021.

the age of toddlers are a major obstacle to public health because almost $50 \%$ of deaths are caused by nutritional problems.

According to the World Health Organization (WHO), in 2018 the prevalence of toddler worldwide who experienced stunting decreased from $32.5 \%$ to $21.9 \%$. However, there are 49 million toddlers who are malnourished and nearly 17 million toddlers are malnourished in 2018. The highest prevalence of malnutrition is in the African continent and parts of the South Asian continent. Many toddlers in Southeast Asia countries are malnourished and stunted. The stunting and malnutrition of toddlers in 2017 in the Southeast Asian continent, the prevalence of toddlers experiencing stunting was $16-44 \%$, the prevalence of toddlers experiencing malnutrition was 9-26\% and malnutrition was $6-13 \%$ (WHO 2020).

Based on data from the South Sulawesi Provincial Health Office, the prevalence of malnutrition of toddlers in 2017 was $1.03 \%$ of the total population, increasing to $2.10 \%$ in 2018 , and in 2019 to $3.48 \%$. In 2016 there was an increase of 6,817 patients from the previous year. It was recorded that during 2018 there were 9,163 cases of malnutrition and in 2019 there was an increase of 15,980 people. (Data from the South Sulawesi Provincial Health Office, 2020). Based on data from the Bone District Health Office in 2018, the number of children under five measured was 12,324 people, as many as $0.10 \%$ of children under five were in the category of poor nutrition, and $4.28 \%$ of children under five were categorized as undernourished. In 2019, the number of toddlers measured was 53,003 people, as many as $0.80 \%$ of malnutrition, and as many as $1.71 \%$ of undernourished. Meanwhile, in 2020 the number of children under five will increase to 52,929 people, $0.75 \%$ of malnutrition, $2.48 \%$ of malnutrition. Based on data from UPT Puskesmas Ajangale in 2018, there were 2251 children under five years old/toddlers and 25 people suffering from malnutrition (7.65\%). In 2019 there were 2340 toddlers,
$11(0.70 \%)$ were in the category of poor nutrition, 69 (4.37\%) were malnourished. In 2020, there were 2349 toddlers. A total of 2 (0.12\%) people were malnourished and 29 (1.72\%) were malnourished (Data from UPT Puskesmas Ajangale 2020)

Based on the problem background above, it is related to the impact caused by the lack of nutrition compliance in toddlers. The researcher is interested in studying more deeply "The Relationship of Mother's Knowledge, Attitude and Behavior to the Compliance of Toddler Nutritional Status at UPT Puskesmas Ajangale in 2021"

\section{LITERATURE REVIEW}

Toddler period is characterized by a very rapid growth and development process with changes that require more high quality nutrients. However, toddlers are a group that is troubled to nutrition and easily suffer from nutritional disorders due to lack of needed food. Food consumption plays an important role in the physical growth and intelligence of children so that food consumption has a major influence on the nutritional status of children to achieve physical growth and intelligence of children (Putri Ariani 2017).

Nutritional status is the level of a person's nutritional state that is found according to the type and severity of the nutritional state; for example over nutrition, good nutrition, less nutrition, and poor nutrition (Ministry of Health 2018). In nutrition, over nutrition and under nutrition are called malnutrition, which is a pathological condition due to a relative or absolute deficiency or excess of one or more nutrients (Mardalena, 2017).

In determining the nutritional status of toddlers, there must be a standard measure which is often referred to as a reference. Anthropometric standard measurement that is currently used in Indonesia is WHO-NCHS. According to Harvard in Supariasa 2012, the classification of nutritional status can be divided into four, namely over nutrition where when the body obtains substances in 
Hasnidar et.al. The relationship between mothers' knowledge, attitude and behavior to meet toddlers' nutritional needs status at the work area of UPT Puskesmas Ajangale 2021.

excessive amounts, causing toxic or harmful effects. Being overweight in toddlers occurs because of an imbalance condition of feeding and excretion, eating too much, exercising too little or both. Good nutrition or optimal nutritional status occurs when the body gets enough nutrients that are used efficiently to allow physical growth, brain development, work ability and general health at the highest possible level. Malnutrition occurs when the body lacks one or more essential substances. Malnutrition is a condition where a person is stated to be undernourished, or in other words his nutritional status is below the average standard. (Almatsier 2011).

Child Anthropometry Standards are used to assess or determine the nutritional status of children. Assessment of the nutritional status of children is carried out by comparing the results of measurements of weight and length/height with the Child Anthropometric Standards. The classification of nutritional status assessment based on the Anthropometric Index is suitable with the nutritional status category in the WHO Child Growth Standards for children aged 0-5 years and The WHO Reference 2007 for children 5-18 years (Termini et al. 2020). Child Anthropometry Standards are based on parameters of weight and length/height which consist of 4 (four) indexes, including:

1. Weight Index by Age

2. Body Length Index by Age or Height by Age

3. Body Weight Index according to Body Length/Height

4. Body Mass Index by Age

There are several factors that affect nutritional status, namely internal and external factors. Internal factors include; food digestibility, health status, infection, age, sex, history of exclusive breastfeeding and weaning food, attitudes and behavior. Meanwhile, external factors include; Knowledge, Parent's education level, Parent's occupation level, Family income level, Family expenditure on food, Number of family members, Food availability, etc.

\section{MATERIALS \& METHODS}

The type of research is descriptive correlational research. Correlational descriptive is a research that is intended to determine whether there is a relationship between two or several variables (Arikunto Suharsimi, 2010). The research design used is a cross sectional study design. Cross sectional. This means that the measurement of variables is only done once at a time (Hidayat 2010).

\section{STATISTICAL ANALYSIS}

Bivariate analysis is used to analyze the relationship between two variables with Chi-Square statistical test. Chi-Square test is used to see the effect of the independent variable on the dependent variable. The analysis technique carried out is Chi-Square analysis using a 95\% confidence degree with $5 \%$, so that if the $\mathrm{P}$ value ( $\mathrm{p}$ value) $<0.05$ means the results of statistical calculations significant (significant) or indicates that there is a relationship between the dependent variable and the independent variable, and if the $p$ value $>0.05$, it means that the results of statistical calculations are not meaningful or there is no relationship between the dependent variable and the independent variable (Sumantri 2011).

\section{RESULT}

\section{Bivariate Analysis}

a. The relationship between mothers' knowledge on nutritional status of toddlers in the work area of the UPT Puskesmas Ajangale

Based on table 1 , it is found that of the 40 respondents, most of mothers who have good knowledge are 27 respondents (67.5\%), mothers who have average knowledge are 5 respondents (12.5\%) and mothers who are less knowledgeable are 8 respondents (20\%). Of the 27 respondents who have good knowledge, there are 25 children with normal nutrition (62,5\%), 2 people with less nutrition (5\%) and there are no toddlers with over nutrition. And of the 8 respondents (20\%) who had less knowledge, 8 people (20\%) had toddlers with less 
Hasnidar et.al. The relationship between mothers' knowledge, attitude and behavior to meet toddlers' nutritional needs status at the work area of UPT Puskesmas Ajangale 2021.

nutrition and did not have toddlers with normal nutrition and more. As for the lowest category, namely mothers who have average knowledge, namely out of 5 respondents, 3 people (7.5\%), have toddlers with over nutrition, 2 people (5\%), and don't have toddlers with low nutritional status. normal nutrition.

Table 1. Frequency Distribution of relationship between mothers' knowledge on nutritional status of toddlers in the work area of the UPT Puskesmas Ajangale

\begin{tabular}{|c|c|c|c|c|c|c|c|c|c|}
\hline \multirow[t]{3}{*}{ Nutrition Knowledge } & \multicolumn{8}{|c|}{ Toddlers Nutrition Status } & \multirow[t]{3}{*}{ p-value } \\
\hline & \multicolumn{2}{|c|}{ Over Nutrition } & \multicolumn{2}{|c|}{ Normal Nutrition } & \multicolumn{2}{|c|}{ Poor Nutrition } & \multicolumn{2}{|c|}{ Total } & \\
\hline & $\mathbf{N}$ & $\%$ & $\mathbf{N}$ & $\%$ & $\mathbf{N}$ & $\%$ & $\mathbf{N}$ & $\%$ & \\
\hline Good & 0 & 0 & 25 & 62,5 & 2 & 5 & 27 & 67,5 & 0,001 \\
\hline Average & 3 & 7,5 & 0 & 0 & 2 & 5 & 5 & 12,5 & \\
\hline Less & 0 & 0 & 0 & 0 & 8 & 20 & 8 & 20 & \\
\hline Total & 3 & 7,5 & 25 & 62,5 & 12 & 30 & 40 & 100 & \\
\hline
\end{tabular}

Based on the results of the chi square test shows $\mathrm{p}$-value $=0.001 \mathrm{p}<0.05$ which means Ha is accepted and $\mathrm{HO}$ is rejected, so it can be concluded that there is a relationship between mothers' nutritional knowledge and the compliance of the nutritional status of toddlers.

\section{b. The Relationship between Mother's Attitude and Nutritional Status of Toddlers in the Work Area of UPT Puskesmas Ajangale}

Table 2. The Relationship between Mother's Attitude and Nutritional Status of Toddlers in the Work Area of UPT Puskesmas Ajangale

\begin{tabular}{|c|c|c|c|c|c|c|c|c|c|}
\hline \multirow[t]{3}{*}{ Mothers' Attitude } & \multicolumn{8}{|c|}{ Toddlers Nutrition Status } & \multirow[t]{3}{*}{ p-value } \\
\hline & \multicolumn{2}{|c|}{ Over Nutrition } & \multicolumn{2}{|c|}{ Normal Nutrition } & \multicolumn{2}{|c|}{ Poor Nutrition } & \multicolumn{2}{|c|}{ Total } & \\
\hline & $\mathbf{N}$ & $\%$ & $\mathbf{N}$ & $\%$ & $\mathbf{N}$ & $\%$ & $\mathbf{N}$ & $\%$ & \\
\hline Good & 0 & 0 & 24 & 63 & 4 & 7 & 28 & 70 & 0,001 \\
\hline Average & 1 & 2,5 & 1 & 2.5 & 1 & 2,5 & 3 & 7,5 & \\
\hline Less & 2 & 5 & 0 & 0 & 7 & 17,5 & 9 & 22,5 & \\
\hline Total & 3 & 7,5 & 25 & 65,5 & 12 & 27 & 40 & 100 & \\
\hline
\end{tabular}

Table 2 shows that of the 40 respondents, most of the mothers in the category of good attitudes were 28 respondents (70\%), mothers who had average attitudes were 3 respondents (7.5\%) and mothers who had poor attitudes were 9 respondents (22, 5\%). Of the 28 respondents who behaved well in keeping nutritional status, 24 people (63\%), had toddlers with normal nutrition, 4 people (7\%), and did not have toddlers with over nutrition. And of the 9 respondents who were lacking in keeping their nutritional status, there were 7 (17.5\%) toddlers with less nutrition, 2 (5\%) overnutrition and no toddlers with normal nutritional status. While the lowest category is the attitude of the mother in the average category, namely out of 3 respondents who are average in keeping nutritional status, having toddlers with more nutritional status, normal and average as much as 1 person $(7.5 \%)$.
Based on the results of the chi square test shows $\mathrm{p}$-value $=0.001 \mathrm{p}<0.05$ which means $\mathrm{Ha}$ is accepted and $\mathrm{HO}$ is rejected so it can be concluded that there is a relationship between mother's attitude and the keeping of toddler nutritional status.

\section{c. The Relationship between Mother's Behavior and Nutritional Status of Toddlers in the Working Area of UPT Puskesmas Ajangale}

Based on table 3 , it was found that from 40 respondents, most of the respondents in the good behavior category are 16 respondents (43\%), mothers who has average behavior are 11 respondents (27.5\%), and mothers who has poor behavior are 13 respondents (29,\%). Of the 16 respondents who behaved well in keeping the nutritional status of toddlers, 16 people (43\%) have toddlers with normal nutrition and did not have toddlers with less 
Hasnidar et.al. The relationship between mothers' knowledge, attitude and behavior to meet toddlers' nutritional needs status at the work area of UPT Puskesmas Ajangale 2021.

and over nutritional status. And for mothers in the category of poor behavior as many as 13 respondents (29.5\%), having toddlers with less nutrition as many as 11 people (27\%) and having toddlers with normal nutrition and more than 1 person $(2.5 \%)$. While the lowest category is mothers in the average behavior category as many as 11 respondents $(27.5 \%$, having toddlers with normal nutritional status as many as 8 people (20\%), and having toddlers with over nutrition as many as 2 respondents (5\%) and having toddlers with under nutrition status of 1 respondent (2.5\%).

Table 3. Frequency Distribution of The Relationship between Mother's Behavior and Nutritional Status of Toddlers in the Working Area of UPT Puskesmas Ajangale

\begin{tabular}{|c|c|c|c|c|c|c|c|c|c|}
\hline \multirow[t]{3}{*}{ Perilaku Ibu } & \multicolumn{8}{|c|}{ Toddlers Nutrition Status } & \multirow[t]{3}{*}{ p-value } \\
\hline & \multicolumn{2}{|c|}{ Over Nutrition } & \multicolumn{2}{|c|}{ Normal Nutrition } & \multicolumn{2}{|c|}{ Poor Nutrition } & \multicolumn{2}{|c|}{ Total } & \\
\hline & $\mathrm{N}$ & $\%$ & $\mathrm{~N}$ & $\%$ & $\mathrm{~N}$ & $\%$ & $\mathrm{n}$ & $\%$ & \\
\hline Good & 0 & 0 & 16 & 43 & 0 & 0 & 16 & 43 & 0,001 \\
\hline Average & 2 & 5 & 8 & 20 & 1 & 2,5 & 11 & 27,5 & \\
\hline Less & 1 & 2,5 & 1 & 2,5 & 11 & 24,5 & 13 & 29.5 & \\
\hline Total & 3 & 7,5 & 25 & 65,5 & 12 & 27 & 40 & 100 & \\
\hline
\end{tabular}

Based on the results of the chi square test shows $\mathrm{p}$-value $=0.001 \mathrm{p}<0.05$ which means $\mathrm{Ha}$ is accepted and $\mathrm{HO}$ is rejected so it can be concluded that there is a relationship between mother's behavior and the keeping of the nutritional status of toddlers

\section{DISCUSSION}

The relationship between mothers' knowledge on nutritional status of toddlers in the work area of the UPT Puskesmas Ajangale

Based on table 1 , it is found that of the 40 respondents, most of mothers who have good knowledge are 27 respondents (67.5\%), mothers who have average knowledge are 5 respondents (12.5\%) and mothers who are less knowledgeable are 8 respondents (20\%). Of the 27 respondents who have good knowledge, have toddlers with normal nutrition as many as 25 respondents (62.5\%), and have toddlers with less nutrition as many as 2 respondents (5\%). And for mothers who have less knowledge as many as 8 respondents (20\%), have toddlers with less nutrition as many as 8 respondents (20\%) and do not have toddlers with normal nutrition and over. As for the lowest category, namely mothers who have average knowledge as many as 5 respondents $(12.5 \%)$, having toddlers with over nutrition as many as 3 respondents (7.5\%), and having toddlers with less nutrition as many as 2 respondents (5\%), and not have children with normal nutritional status. Based on the results of the Chi-Square test, it shows that $\mathrm{p}$-value = $0.001 \mathrm{p}<0.05$, which means Ha is accepted and $\mathrm{HO}$ is rejected, so it can be concluded that there is a relationship between knowledge and the keeping of the nutritional status of toddlers.

A person's level of education will be closely related to knowledge about sources of nutrition and good variants of food for family consumption. Educated housewives will tend to choose food that is better in quality and quantity, compared to mothers with lower education (Meryana 2014).

The level of knowledge on nutrition will greatly affect attitudes and actions in choosing food and will affect the nutritional state of the individual. Lack of nutritional knowledge or lack of applying nutritional knowledge in daily life can cause nutritional problems in a person. This is in line with research conducted by (Weya et al. 2018) showing that of the 21 mothers with less knowledge there are 20 people (95.2\%) with poor nutritional status and people (4.8\%) with good nutritional status. Meanwhile, from 79 mothers with good knowledge, there are 16 (20.3\%) with poor nutritional status and 63 people (79.7\%) with good nutritional status. NS chi square statistical test results at a significance value of $95 \%$ (P $=0.05$ ) obtained a p-value of 0.000 or $\mathrm{p}<$ (0.05). This means that there is a significant relationship between mother's knowledge 
Hasnidar et.al. The relationship between mothers' knowledge, attitude and behavior to meet toddlers' nutritional needs status at the work area of UPT Puskesmas Ajangale 2021.

and nutritional status of toddlers in Puncak, Puncak Jaya District. The result of the RP value = 4.702; CI95\% (3.005 - 7.359) interprets that respondents with less knowledge of the risk with poor nutritional status of toddlers are 4,702 times higher than those with good knowledge.

This is in line with research conducted by Melly Anida, 2015 that based on the results of the Fisher test analysis, the $\mathrm{p}$-value is 0.000 (p-value $<0.05$ ) and the OR is 62.44. This shows that there is a significant relationship between the mother's levels of knowledge on the nutritional status of toddlers. And the OR value of 62,438 means that mothers with lack level knowledge of nutrition, she is 62 times more at risk of having a toddler with poor nutritional status. Mother's knowledge is very necessary in an effort to improve the nutritional status of her toddler well, the higher the mother's knowledge, the more is done in regulating food so that it becomes more useful for her toddler's growth.

\section{The Relationship between Mother's Attitude and Nutritional Status of Toddlers in the Work Area of UPT Puskesmas Ajangale}

Based on table 2, it is found that of the 40 respondents, most of the mothers in the category of good attitudes are 28 respondents (70\%), mothers who have average attitudes are 3 respondents (7.5\%) and mothers who have poor attitudes are 9 respondents (22.5\%). Of the 28 respondents who behaved well in keeping nutritional status, 24 respondents (63\%), have toddlers with normal nutrition, 4 respondents (7\%), and do not have toddlers with over nutrition. Of the 9 respondents who are undernourished, 7 respondents $(17.5 \%)$ have toddlers with malnutrition, 2 respondents have more nutrition (5\%) and do not have toddlers with normal nutritional status. While the lowest category is the attitude of the mother in the average category, namely from 3 respondents (7.5\%), having toddlers with over, normal and less nutritional status as many as 1 respondent (2.5\%).
Based on the results of the ChiSquare test, it shows that $\mathrm{p}$-value $=0.001 \mathrm{p}$ $<0.05$, which means $\mathrm{Ha}$ is accepted and $\mathrm{H} 0$ is rejected, so it can be concluded that there is a relationship between mother's attitude and the keeping of Toddler Nutritional status. Attitude is a person's reaction or response to a stimulus or object. Attitudes in everyday life are emotional reactions to social stimuli. There are 3 attitude structures consisting of cognitive, affective and conative. The cognitive component means a person's beliefs about what is valid or what is true for the attitude object. Trust comes from what has been seen or from personal experience and knowledge possessed. Mother's attitude in keeping nutritional status is behavior in compliance of nutritional supplementary in children. The attitude taken will affect the general nutritional status of children. A good mother's attitude will affect the increase in mother's effort to increase child nutritional supplementary so that the nutritional status of toddlers becomes normal. On the other hand, if the mother's attitude is average, the mother's effort to meet the nutritional status of toddlers will be reduced so that the nutritional status of children will also be less. This is in line with research of Wulandari, 2019 which explains that there is a significant relationship between mothers' attitudes towards the nutritional status of toddlers in the Sei Kera Hilir II sub-district, Medan District, with a P value of less than 0.05 , namely ( $p=0.017$ ). Mothers who have good attitudes are 5 times more likely to have their toddlers have a good nutritional status than mothers who have poor attitudes. According to Dewi's 2018 research in (Sulistyoningrum \& Hadiyanti, 2018) shows different things, Dewi's research shows that there is no relationship between mother's attitude and toddler's nutritional status. Based on the results of the study, it is found that the frequency of respondents with poor attitudes with abnormal nutritional status (42.9\%) was smaller than normal nutritional status (57.1\%), and good attitudes with abnormal 
Hasnidar et.al. The relationship between mothers' knowledge, attitude and behavior to meet toddlers' nutritional needs status at the work area of UPT Puskesmas Ajangale 2021.

nutritional status $(87.5 \%)$ greater than the normal nutritional status (12.5\%). The results of statistical tests with fisher's exact between the mother's attitude variable and the nutritional status of toddlers obtained $\mathrm{p}=0.119(\mathrm{p}>0.05)$, which means that there is no relationship between mother's attitude and nutritional status of toddlers. Sukandar found that Based on the analysis of GLM, it was found that intervention had significant impact on the nutritional status of toddlers based on WAZ (the Z-score of body weight/age) (Table 6). Intervention did not have significant effects on the nutritional status according to HAZ (Z-score of height for age) or WHZ (Z-score of weight for height). This is possible because the fivemonth intervention was not yet enough to improve the nutritional status”.

\section{The Relationship between Mother's Behavior and Nutritional Status of Toddlers in the Working Area of UPT Puskesmas Ajangale}

Table 3 shows that from 40 respondents, most of the respondents in the good behavior category are 16 respondents (43\%), mothers who have average behavior are 11 respondents (27.5\%), and mothers who have poor behavior are 13 respondents (29,\%). Of the 16 respondents who behaved well in keeping the nutritional status of toddlers, 16 people $(43 \%)$ have toddlers with normal nutrition and do not have toddlers with less and over nutritional status. And for mothers in the category of poor behavior as many as 13 respondents (29.5\%), having toddlers with less nutrition as many as 11 people (27\%) and having toddlers with normal nutrition and more than 1 person (2.5\%). While the lowest category is mothers in the average behavior category as many as 11 respondents $(27.5 \%$, having toddlers with normal nutritional status as many as 8 people (20\%), and having toddlers with more nutrition as many as 2 respondents (5\%) and having toddlers with under nutrition status of 1 respondent (2.5\%).Based on the results of the chi square test shows $\mathrm{p}$-value $=0.001 \mathrm{p}<0.05$, which means $\mathrm{Ha}$ is accepted and $\mathrm{HO}$ is rejected so that it can be concluded that there is a relationship between mother's behavior and the keeping of the nutritional status of toddlers. Behavior is the result of experience and the process of interaction with the environment in the form of knowledge, attitudes and actions so that a balanced state is obtained between the driving and restraining forces (Maulana 2010). Mothers' behavior can be seen from her pregnant period until her 2 years baby growth.

A healthy child is only be born to a mother who maintains her pregnancy from adequate nutritional supplementary (micronutrients and protein). Pregnant women who experience chronic malnutrition since their pregnancy will be at risk of giving birth to unhealthy children, or low birth weight (Priyatna, 2014). The behavior of mothers in keeping nutrition in children in the first 1000 days of life or Golden Period during pregnancy can be seen from eating more (two servings) and a variety of slide dishes, vegetables and fruit, so that the nutritional needs of the fetus are met adequately from the beginning and during pregnancy, and take 1 iron tablet (supplement) a day, so a total of at least 90 tablets during pregnancy, Don't smoke, don't drink fizzy drinks, alcohol, don't eat instant noodles as a staple or main food, avoid food with preservatives, and don't take medicine without a doctor's prescription, attend classes for pregnant women, and perform breast care to ensure the success of breastfeeding, as well as make prenatal visits to midwives, at least 4 times during pregnancy to monitor fetal growth (Irawati 2018).

Based on research of Melly Anida, 2015 there is a significant relationship between mother's actions on the nutritional status of toddlers; an attitude is not always manifested in an action. This is in line with the fact that a positive attitude towards health values does not always manifest in a real action and it is proven that there are still mothers who are still have limitation in 
Hasnidar et.al. The relationship between mothers' knowledge, attitude and behavior to meet toddlers' nutritional needs status at the work area of UPT Puskesmas Ajangale 2021.

paying attention to the nutrition of their toddlers. Actions related to the nutritional status of toddlers can be seen from the various habits of mothers who are still imprecise in serving the nutritional needs of their children. However, this study is different from research from Egha, 2012 with the title "Relationship of Sociodemographic and Dietary Patterns with Nutritional Status of State School Children in 16 Ulu Palembang Village" which states that there is no relationship between Mother's Feeding Behavior and nutritional status of toddlers due to various factors. Factors affecting the nutritional status of children apart from the norms or habits of the respondents are genetic factors or heredity factors which are also an important problem in nutritional problems. Children who have a thin genetic factor, no matter how much the amount of food consumed will not affect the nutritional status of toddlers, and vice versa with children who have a fat heredity factor.

According to Blum's theory, heredity (genetic) is a factor that already exists in humans that is brought from birth that can be related to health status. According to Blum stated that behavior is the second factor that affects the degree of public health because a healthy or unhealthy environment for individual, family and community health is highly dependent on human behavior itself. In addition, it is also influenced by habits, customs, habits, beliefs, socio-economic education, and other behaviors that is closed respectively.

\section{CONCLUSION}

Based on the results of the chisquare test obtained $\mathrm{p}$-value $=0.001 \mathrm{p}<0.05$ knowledge, attitude and behavior, which means that there is a relationship between knowledge, attitudes and behavior of mothers on the meeting of nutritional status needs in toddlers.

\section{Acknowledgement: None}

\section{Conflict of Interest: None}

\section{Source of Funding: None}

\section{Ethical Approval: Approved}

\section{REFERENCES}

1. Almatsier, S. 2011. Gizi Seimbang Dalam Daur Kehidupan. Jakarta: PT Gramedia Pustaka Utama.

2. Data UPT Puskesmas Ajangale. 2020. "Cakupan Pemberian ASI Eksklusif Di Kabupaten Bone.” 2020.

3. Departemen Kesehatan. 2018. Riset Kesehatan Dasar (Riskesdas), Laporan Nasional 2007. Badan Pene. Jakarta.

4. Egha. 2012. "Hubungan Faktor Dan Pola Makan Dengan Status Gizi Anak Sekolah Negri Di Kelurahan 16 Ulu Palembang Tahun 2012” 1.

5. Hidayat, Alimul. 2010. Metode Penelitian Kesehatan Paradigma Kuantitatif. Jakarta: Helath Books.

6. Irawati. 2018. "Pengetahuan Gizi Murid SD Dan SMP Di Kodya Bogor. Bogor: Pusat Penelitian Dan Pengembangan Gizi Dan Makanan Departemen. Kesehatan.” Juranal Kebidanan. https://ejournal2.litbang.kemkes.go.id.

7. Mardalena, Ida. 2017. Dasar-Dasar Ilmu Gizi Dalam Keperawatan. 1st ed. Yogyakarta: Pustaka Baru Press.

8. Maulana. 2010. Gizi Dalam Daur Kehidupan. Jakarta: EGC.

9. Melly Anida. 2015. "Hubungan Pengetahuan Ibu, Sikap Dan Perilaku Terhadap Status Gizi Balita Pada Komunitas Nelayan Di Kota Karang Raya Teluk Betung Timur Bandar Lampung.” Juranal Kebidanan 4 (8): 167. anidamelly@rocketmail.com.

10. Meryana. 2014. Gizi Dan Kesehatan Balita. 1st ed. Jakarta: Kencana.

11. Priyatna. 2014. Prinsip Dasar Ilmu Gizi. Jakarta: PT Gramedia Pustaka.

12. Putri Ariani, A. 2017. Ilmu Gizi Dilengkapi Dengan Standar Penilaian Status Gizi Dan Daftar Komposisi Bahan Makanan. Yogyakarta: Nuha Medika.

13. Profil Dinkes Sulsel, Dinkes Provinsi Sulawesi. 2020. "Profil Dinas Kesehatan Provinsi Sulawesi Selatan.” Dinkes Provinsi Sulsel. 2020.

14. Soekirman. 2011. Ilmu Gizi Dan Aplikasinya Untuk Keluarga Dan 
Hasnidar et.al. The relationship between mothers' knowledge, attitude and behavior to meet toddlers' nutritional needs status at the work area of UPT Puskesmas Ajangale 2021.

Masyarakat. Jakarta: Departemen Pendidikan Nasional.

15. Suharsimi, Arikunto. 2010. Prosedur Penelitian Suatu Pendekatan Praktek. Jakarta: Rineka Cipta.

16. Sukandar, Dadang, Ali Khomsan, Faisal Anwar, and Hadi Riyadi. n.d. "Nutrition Knowledge, Attitude, and Practice of Mothers and Children Nutritional Status Improved after Five Months Nutrition Education Intervention” 4531: 424-42.

17. Sulistyoningrum, Dewi, and Tuti Hadiyanti. 2018. "Relationship Between Knowledge, Attitude, and Behavior of Mothers with Nutritional Status in Toddlers at the Nutrition Recovery Post, Randugunting Village, Tegal City 2018,” 99-107.

18. Sumantri. 2011. Metode Penelitian Kesehatan. Jakarta: Andi Offset.

19. Termini, End, F Project Description, Duportail Street, B Stip Id, Expenditure Schedule, Federal Fund Code, Federal Funds, et al. 2020. "Standar Antropometri Berdasarkan Peraturan Mentri Kesehatan Republik Indonesia” 21 (1): 1-9.

20. UNICEF. 2018. "Improving Child Nutrition The Achievable Imperative for Global Progress.”

Diakses:www.Unicef.Org/Media/Files/Nutri tion_report_2013.Pdftanggal 24 Desember
2013.

2018. www.unicef.org/media/files/nutrition_report 2013.

21. Weya, Arinius, A L Rantetampang, Rosmin Tingginehe, and Anwar Mallongi. 2018. "Factors Affecting Nutrient Status of Children Under Five Years at Puncak Jaya District Sub Province Papuan.” International Journal of Science and Healthcare Research 3 (4): 70-80.

22. WHO. 2010. "Interpretation Guide Nutrition Landscape Information System (NLIS).” 2010.

23. Wulandari, Tri. 2019. "Hubungan Pengetahuan, Sikap Dan Tindakan Ibu Dengan Status Gizi Anak Balita Di Kelurahan Sei Kera Hilir Ii Kecamatan Medan Perjuangan.” Jurnal Kebidanan Kestra (Jkk) 2 (1): 9-17. https://doi.org/10.35451/jkk.v2i1.233.

How to cite this article: Hasnidar, Mustar. The relationship between mothers' knowledge, attitude and behavior to meet toddlers' nutritional needs status at the work area of UPT Puskesmas Ajangale 2021. International Journal of Science \& Healthcare Research. 2021; 6(4): 269-277. DOI: https://doi.org/10. 52403/ijshr.20211038 